\title{
INTRA-URBAN TRAFFIC AND PARKING DEMAND IN UYO URBAN AREA
}

\author{
J. U. OBOT, E. E. ETIM AND J. ATSER
}

(Received 10, February 2009; Revision Accepted 20, October 2009)

\begin{abstract}
In Nigeria, the dominant mode of intra-urban mobility is the automobile motor vehicle. However, parking facilities as element of urban transportation development seems to be neglected in the face of increasing car ownership on the hand and increasing activities which generate enormous parking demand on the other. The aim of this study is to examine the intra-urban circulation and parking demand against the background of noticeable problems of parking in Uyo metropolis. An empirical design approach was employed in the investigation and vehicular trip generation count at designated activity areas was carried out between the hours of Bam 11am from Monday to Friday. Regression models were employed to measure the relationship between parking demand and parking space capacity per activity area. The result shows that while parking space demand is very high, the activity areas with less parking facilities, receives less patronage. The study recommends a comprehensive parking programme for Uyo metropolis
\end{abstract}

\section{INTRODUCTION}

A city is characterized by various landuse activities and pattern of circulation within it is related to the function of those activities and their spatial distribution. The efficiency of this circulation depends primarily upon existing transportation system and parking is a major component of this system. Landuse activities can be adversely affected if parking is not provided in relation to other urban activities (Kaiser et al, 1995).

Throughout history the need for efficient urban circulation has ben much the same and problem of urban transportation first became manifest in $1^{\text {st }}$ Century $A D$ when the Roman Municipal Government in an attempt to decongest its street, restricted vehicular traffic to night hours; and Rome was then the only truly "big city" in the Western world (Dyckman, 1972). In those days, urban areas were generally small enough to permit travel by foot, horse, cart,or other primitive means. Today, cities worldwide are still grappling with similar problems of reducing congestion on their roads and prviding adequate parking for the swarming vehivular population.

In Nigeria as elsewhere where cars are one of the dominant modes of transportation, urban circulation is one of the most obvious problems and parking seems to be an overlooked element of transportation development. Venues of activities such as offices, markets, shops, sports, churches and similar places often generate enourmous parking demands, and the difficulty of parking vehicles at desired destinations particularly when located within the central areas of the city constitutes a major problem, becoming cumbersome and phenomenal in the face of increasing number of private car ownership. Several studies have shown that improvements in living standards as a result of wage increases contribute almost as much as the growth of cities to contemporary urban traffic conditions in Nigeria(Tanimowo and Atolagba, 2006; Obot and Umoh, 2007).

In Uyo, intra-city circulation and parking is one of the most noticeable problems in the city
J. U. Obot, Department of Geography, Faculty of Environmental Studies, University of Uyo,Uyo
E. E. Etim, Department of Landscape Architect, Faculty of Environmental Studies, University of Uyo,Uyo
J. Atser, Department of Urban Planning, Faculty of Environmental Studies, University of Uyo,Uyo 
as there are no designated parking spaces except the recent one provided at the lbom Plaza, which has already proved insufficient. Unauthorized and indiscriminate parking along streets within the urban core is a severe impediment to smooth urban movement and is indicative of lack of attention to this important aspect of transportation.

This study examines the intra-urban circulation in Uyo with particular reference to parking, relating it to land use types and trip generation that have given vent to the problem of parking within the urban core. The aim is to analyze the magnitude of parking problem as a result of trip generation within the urban core and also to offer a planning framework within which parking problem could be tackled to satisfy smooth intra-urban travel within the city.

\section{CONCEPTUAL FRAMEWORK}

The spatial organization of a city defines interactions within it and the efficiency of this interaction is a function of the economy of the city and the ease with which movement is undertaken (Tanimowo and Atolagba, 2006). Many approaches have been adopted to explain this interaction within a city in terms of its spatial organization and land use activities. Johnson (1972) has provided the three of theories.

One was pronounced by Ernest Burgess (1923). Known as the Concentric Theory of land use location, it assumed that development of a city follows an outward growth from its central area in a series of concentric zones and that intra-city movements primarily influence the shape of such growth. The Sector Theory of Hoyt and Davis (1939) traced the historical growth of cities along travel routes in which different parts of sectors of the city take a star-like shape as defined by route ways from the centre to the suburbs. Harris and Ulman (1945) in their Multinuclei Model pronounced that there were multiple centers in different parts of the city, each specializing in different types of land use.

Generally, what appear to be common to these models are the functions or activities in a city that are determined by its economy and the interaction of people with the activities through intra-urban movement. Specifically, what this means is that there can never be a city without movement among land uses within it and that "circulation pervades every aspect of urban life" (Etim, 2007 pp. 200).
Ogunsanya and Fadare (1986) have viewed urban circulation from four major perspectives. The first involves traffic congestion, parking problems, accidents, and environmental pollution. The second includes route adequacy, poor traffic management, and human misuse of roads, increased demand and poor nature or absence of transport planning. The third refers to financial constraint, political decision and absence of data. The fourth is the method of uncoordinated management system. Some aspects of these perspectives are relevant to this study.

\section{THE STUDY AREA}

Uyo is rapidly emerging as a metropolitan city. Its upgrading to the status of a state capital in 1987 gave a powerful impetus to its physical and economic growth. The development rate is further accentuated by the abrogation of onshore/offshore dichotomy in 1991 and the subsequent increase in oil revenue accruable to it since 2003 , consequently raising the general standard of living for the citizenry.

The most noticeable of the physical expansion of the city is its population growth and urban landmass. The estimated amount of the built-up area from available landuse maps has shown immense increase from $5.30 \mathrm{~km} 2$ in 1960 when the city was a mere district headquaters to $186.30 \mathrm{~km} 2$ in 2005 as a capital city. The population rose from 87,311 persons in 1987 when the city achieved its new status to 518511 in 2006 during the last national census exercise. At an annual growth rate of 5 percent, the projected figure for the year 2010 is expected to be one million.

The increase in land mass and population is evident in economic activities including daily trade in commodities carried out in a network of traditional and modern markets, hotels and guesthouses dotting the landscape of both inner and outskirts of the city. These activities have equally increased the number of traffic and travel volume in the city as people travel between their homes and jobs, get services, shop and conduct businesses and so on.

In addition, the city being strategically located in the heart of the state linked by roads to all its local government areas receives considerable daily road traffic from the neighboring states. These intra-city and interstate journeys are largely responsible for the peak traffic flow in the central city. Space demand to 
park vehicles at places of destinations is high but almost all the commercial and business places located within the central city have no designated parking areas. Consequently, vehicles are usually parked indiscriminately around these places, and thus contribute enormously to traffic obstruction and chaos.

\section{METHOD OF STUDY}

The study adopts an empirical design approach to investigate problem of vehicular parking spaces within Uyo urban core. Using field observation, vehicular trip generation count was conducted at designated activity areas spatially spread out in the study area. The number of vehicular traffic to activity areas was measured against existing parking space in order to assess the level of parking convenience available per activity area. The vehicular trip generation count was carried out between the hours of $8 a m-11 a m$ considered as the peak period of transaction in the activity areas. The count was done for 5 working days (Monday-Friday) and the average was taken as the total vehicular traffic count per 3 hour period per activity area. The analysis of the relationship between total vehicular traffic count and parking space capacity was performed using linear, quadratic and exponential regression models.

\section{ANALYSIS OF URBAN ROAD NETWORK}

An understanding of the nature and characteristics of road network in Uyo urban area is necessary to provide the basis for assessing vehicular trip generation and parking problem. Description of road network in the city therefore becomes imperative.
Uyo as a city predated modern planning efforts, being in existence long before the introduction of vehicular mode of transportation. This should explain the spontaneous nature of many of its streets, and their poor alignments. What now constitutes road network in Uyo took its origin from a central point that was known as the "Circus" (now "Ibom Connection") from which five premier roads, namely Ikot Ekpene, Wellington Bassey, Oron, Aka and Abak spread out radially. Rings of street network were later added and the city assumed a radial structure that somewhat resembles Ernest Burgess' (1923) Concentric Model of city development. A new master plan for the city following its upgrading to a capital city has successfully interwoven this radial pattern by adding another set of ring roads (Table1).

The poor layouts and alignments of many streets in the city create friction points at intersections. Many of the streets have pavements of less than 7 meter wide and their narrow widths are responsible for lack of pedestrian side walks and on-street parking along them. Many streets also experience reduction in their carriage capacity during rainy season as a result of poor drainage system. Cases of flooding often lead to traffic diversion, thus increasing travel time. A concomitance of the problem of poor road network design is the absence of parking facilities along the roads and consequently, indiscriminate parking of vehicles and dropping off of passengers along the carriage way has further compounded intra-urban circulation difficulties in the urban core.

\section{Table 1: Old and New Ring Road Structures of Uyo}

a) The old structure

\begin{tabular}{|l|l|}
\hline Hierarchy & \multicolumn{1}{|c|}{ Ring Structure } \\
\hline $1^{\text {st }}$ Ring & Etuk Street- Iqwe Street- Ibanga Street-Ekpenyong Street \\
\hline $2^{\text {nd }}$ Ring & Nsentip Street-Enwe Street- Udo Obot Street \\
\hline $3^{\text {rd }}$ Ring & Eka Str.- Udi Str.- Nsit Str.- Udotong Ubo Str. Udosen Uko Str. \\
\hline $4^{\text {th }}$ Ring & Epkanya Str.- Udobio Str.-Udo Eduok Str.-Udo Ekpo Inyang Str. \\
\hline $5^{\text {th }}$ Ring & $\begin{array}{l}\text { Iboko Stt.- Nepa Line- Umoren Str.- IkotAbasi Str.- Akpan Etuk Str.-Utang } \\
\text { Str.-Udo Str. }\end{array}$ \\
\hline $6^{\text {th }}$ Ring & $\begin{array}{l}\text { Ebong Essien Str.- Akpan Essien Str.-Ikono Str.-William Str.-Afia Etoi Str.- } \\
\text { Uruan Srt.- Brook Str. }\end{array}$ \\
\hline $7^{\text {th }}$ Ring & $\begin{array}{l}\text { Terbanacle Str.-Nkemba Str.- UkanaOffot Str.-Obio Imo Str. Bennett Bassey } \\
\text { Str.- Etiebet Ave. -Sam Edem Str. }\end{array}$ \\
\hline
\end{tabular}


b)The New Structure

\begin{tabular}{|l|l|}
\hline Hierarchy & \multicolumn{1}{|c|}{ Ring Structure } \\
\hline $1^{\text {st }}$ Ring & Ibom Connection By-pass \\
\hline $2 n^{\text {d }}$ Ring & Atiku Abubakar Ave.- Ibrahim Babangida Ave.-Nsikak Eduok Ave. \\
\hline $3^{\text {rd }}$ Ring & Ring Road 2(from Abak Road, Efiat offot)-Udo Udoma Ave.-Osong Ama Layout \\
\hline $4^{\text {th }}$ Ring & Ring Road 3 East-West of Uyo capital city \\
\hline 5 thRing & The peripheral Ring road of Uyo capital city \\
\hline
\end{tabular}

Source: Udom (2003).

\section{Current Measures to improve Conditions of Urban Roads in Uyo}

The status of Uyo as the state capital has already been noted as the reason for the phenomenal growth of service/business and commercial activities that have given rise to increase in daily travel volume as a result of corresponding increase in number of vehicles in the city, which has implications for parking demand. This increase has become noticeable partly because the roads in the city were not built to accommodate high volumes of traffic and parking. The following measures have been taken by the state government as:

1 Construction of Ring Roads: One solution that was immediately offered by the new Master plan to decongest the central part of the city was the construction of a partial loop (Ring Road 1) around the Ibom Connection to divert much traffic from coming into it. The loop now runs from lkot Ekpene Road cutting off Abak and Aka Roads from entering the junction and terminating at Oron Road. By this connection, a pedestrian plaza was created around lbom Connection (Fig.1). The plaza, which was completed in 2002. turned out to be a multipurpose business and recreation project comprising a flea market extension, shops, café, a pedestrian floyer, a post office, an amphiteater and a car park. The incorporation of a flea market was informed by the need to relocate street trading along Etuk Street, Aka and Abak Roads, which were always clustered, interfering with smooth movement of traffic within the urban core. The creation of the car park was meant to accommodate cars and to discourage indiscriminate parking within the precinet. Unathourized parking within the central city, which is often of perpendicular configuration, contributes much to traffic obstruction as cars often back out directly onto the street, causing serious traffic nuisance. The new ring roads were meant to provide separation of through traffic from local traffic coming into the city. Nonpavement of all the new ring roads in the city has not made complete separation possible. However, the construction of the second ring road, which incorporates Nsikak Eduok, Ibrahim Babangida, Atiku Abubakar Avenues, and the partial construction of the third one, which incorporates Udo Udoma Avenue and OsongAma Road, has helped in this regard

2 Re-surfacing of Urban Roads: The reconstruction of the five premier roads was undertaken to improve traffic flow in the city. The dualization of lkot Ekpene, Oron and Abak Roads, which are inter state trunk $A$ routes, has been completed. Re-surfacing of many streets was also undertaken to improve the serviceability of road network. The total length of roads in the city as at the end of 2005 was 75.6 $\mathrm{km}$ of which 70 percent has been sealed (State Ministry of Works and Transport, 2006). Although the conditions of urban roads have improved, the problem of parking still persists. 


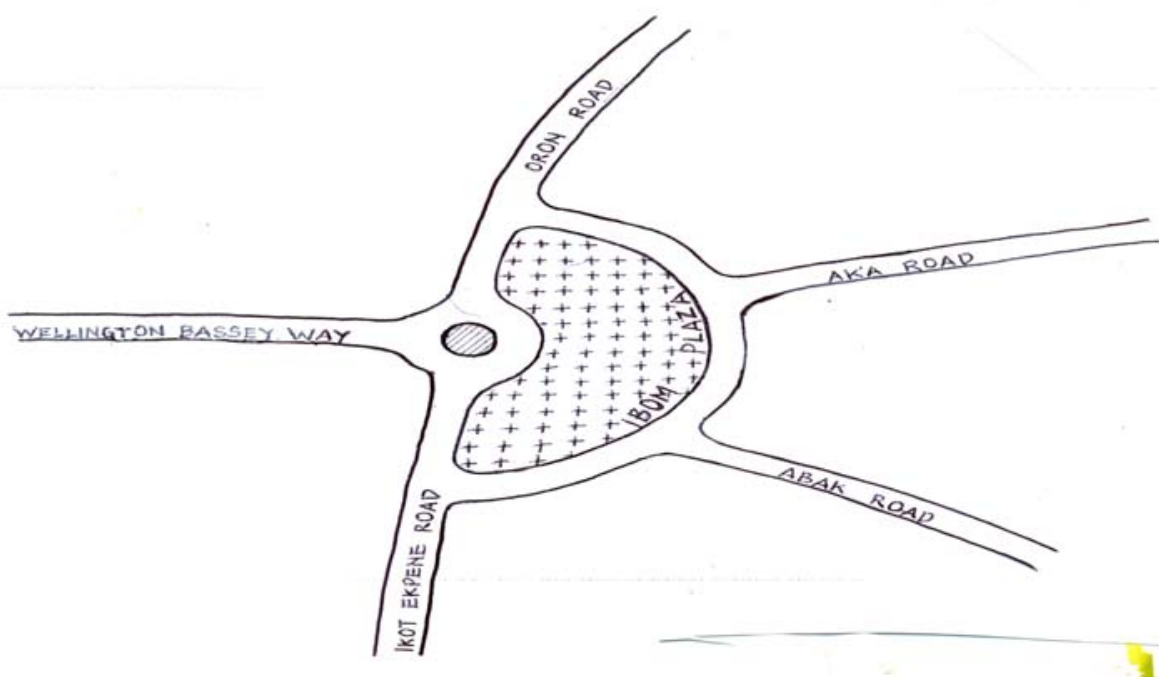

Fig.1: The loop around Ibom Connection(Master Plan of Uyo, 1998)

3. Re-location of Uyo Main Market: The establishment of Akpan Andem Market along Udo Udoma Street and new one at Ekit Itam was meant to relocate the Uyo Main Market and reduce travel volume generated by trading around the urban core. Government's recent forceful relocation of these activities will greatly enhance smooth circulation around the area.

The above measures by the state government to improve road conditions are not far-reaching enough and have not significantly improved the traffic situation in the city. A number of factors, however, can explain their seemingly failure. Firstly, the loop arrangement could not have improved the traffic situation around the Ibom Connection because of its nearness to the junction to make any significant impact on traffic diversion (Obot and Umoh, 2007). Secondly, the car park at the plaza, which is the first of its kind in the city, has been found to be inadequate and of poor design configuration to meet parking demands in the central area (Etim, 2007). Thirdly and also relating to parking problem in the city, the reconstruction of the streets in the city and the construction of the second Ring Road have failed to make provision for pedestrian traffic and on-street parking, thus worsening travel and parking situation within the city. Heavy traffic along these streets makes both pedestrian circulation and car parking quite challenging.

Fourthly, the measures introduced to curb illegal motor parks and trading on streets of the central city so far lack restrictive enactments to give legal teeth to them. Government action on illegal activities in the city has become akin to something of will-o-the wisps. Lastly, the travel situation in Uyo is further snarled by the inability of government to regulate the increasing volume and operation of irate motorcycle traffic on the urban streets. This mode of public transportation represents a novel trend in the use of motorcycle to enable people without access to cars to travel and Table 3 shows that motorcycle mode of transportation now accounts for a higher proportion of personal journeys in Uyo. However, it is arguable if the advantages of the rising profile of the motorcycle mode of transportation are worth in the daily loss of lives and bodily injuries on our roads (Etim 2007).

\section{ANALYSIS OF TRIP GENERATION AND PARKING DEMAND}

Intra-urban journeys in Uyo indicate the form of spatial interaction of various land uses, which also provide a measure of the spatial organization of the city. The travel efficiency relates to the cost of movement in time value, in distance, and in convenience. Convenience in this study relates specifically to parking. Trip generation and attracting capacity of land use in terms of the number of vehicles and parking demand is used as a gauge to assess the functional role of each zone in terms of space efficiency, Table 2 provides data on vehicular traffic count as a measure of parking demand per activity area and the actual parking capacity in existence. 
TABLE 2: PARKING DEMAND AND PARKING CAPACITY IN DESIGNATED ACTIVITY SPACE IN UYO URBAN

\begin{tabular}{|l|l|l|l|l|}
\hline SIN & ACTIVITY AREA & $\begin{array}{l}\text { PARKINGSPACE } \\
\text { CAPACITY }\end{array}$ & $\begin{array}{l}\text { PARKING } \\
\text { DEMAND }\end{array}$ & $\begin{array}{l}\text { MEAN PARKING } \\
\text { DEMANDIHOUR }\end{array}$ \\
\hline 1 & Akwa savings and loans & 6 & 37 & 12 \\
\hline 2 & A.D.C. office & 4 & 21 & 7 \\
\hline 3 & Entaco & 7 & 22 & 7 \\
\hline 4 & Intercontinental Bank & 10 & 57 & 19 \\
\hline 5 & ECO Bank & 5 & 44 & 14 \\
\hline 6 & Celtel office & 7 & 16 & 5 \\
\hline 7 & Oceanic Bank & 5 & 35 & 11 \\
\hline 8 & Shopping Complex & 30 & 197 & 65 \\
\hline 9 & Diamond Bank & 9 & 29 & 9 \\
\hline 10 & Bank PHB & 4 & 35 & 11 \\
\hline 11 & Fidelity Bank & 3 & 21 & 7 \\
\hline 12 & Union Bank & 12 & 160 & 53 \\
\hline 13 & UBA & 47 & 180 & 60 \\
\hline 14 & First Bank & 22 & 107 & 35 \\
\hline
\end{tabular}

Source; Author's Field work (2008)

Table 2 shows the parking demand in the designated activity areas of the city and is indicative of the high demand when compared with the existing parking spaces, and reflects the volume of vehicular traffic per hour to these activity areas. Only two of the activity areas, i.e. Entaco Pharmaceutical shop and Diamond Bank have adequate hourly parking. At Shopping Complex, Union Bank and UBA, parking conditions are very acute and existing demand outweighs the parking space. What this development implies is that excess vehicular traffic in these activity areas is parked along the roads. It is also obvious that the volume of vehicular traffic to activity areas is related to the amount of parking space available. Where parking space is enough, the volume of trip generated is therefore high.

The nature of this relationship can be further expressed statistically as shown in Table 3. The three models show significant relationships, confirming that parking demand in activity areas is directly influenced by the degree of parking space available. It would seem that patronage of activity areas will increase if more parking spaces are provided.

TABLE 3: SUMMARY STATISTICS OF REGRESSION MODELS

\begin{tabular}{|l|l|l|l|}
\hline PARAMETERS & LINEAR MODEL & QUADRATIC MODEL & EXPONENTIAL MODEL \\
\hline R & 0.848 & 0.892 & 0.793 \\
\hline R2 & 0.718 & 0.796 & 0.629 \\
\hline R2 Adjusted & 0.695 & 0.759 & 0.598 \\
\hline Standard error of Est. & 35.50 & 31.50 & 54.40 \\
\hline F & 30.60 & 21.50 & 20.60 \\
\hline Sig. F & 0.000 & 0.000 & 0.001 \\
\hline B & 4.336 & -0.120 & 0.054 \\
\hline Beta & 0.848 & -1.129 & 0.793 \\
\hline
\end{tabular}

Independent variable is parking space capacity

Dependent variable is parking demand

In other words, many vehicular owners would seem to be discouraged patronizing certain activity areas as a result of insufficient parking facilities.

From Table 3 and Graph 1, the significance of the quadratic model over other models is apparent because it has higher value of 79.6 percent of the variance observed than 
Linear model with 71.8 percent while Exponential model records 62.9 percent. The magnitude and direction of influence is indicated by the $B$ and Beta values. The negative B-value $(-0.120)$ implies what an increase by a unit change in parking space is expected to yield a negative change in parking demand by 0.120 units. The sign of the partial regression coefficient (Beta) is also significantly negative, implying that an increase in parking space will bring about a corresponding decrease in parking demand by 1.127 units for every unit change in parking capacity.

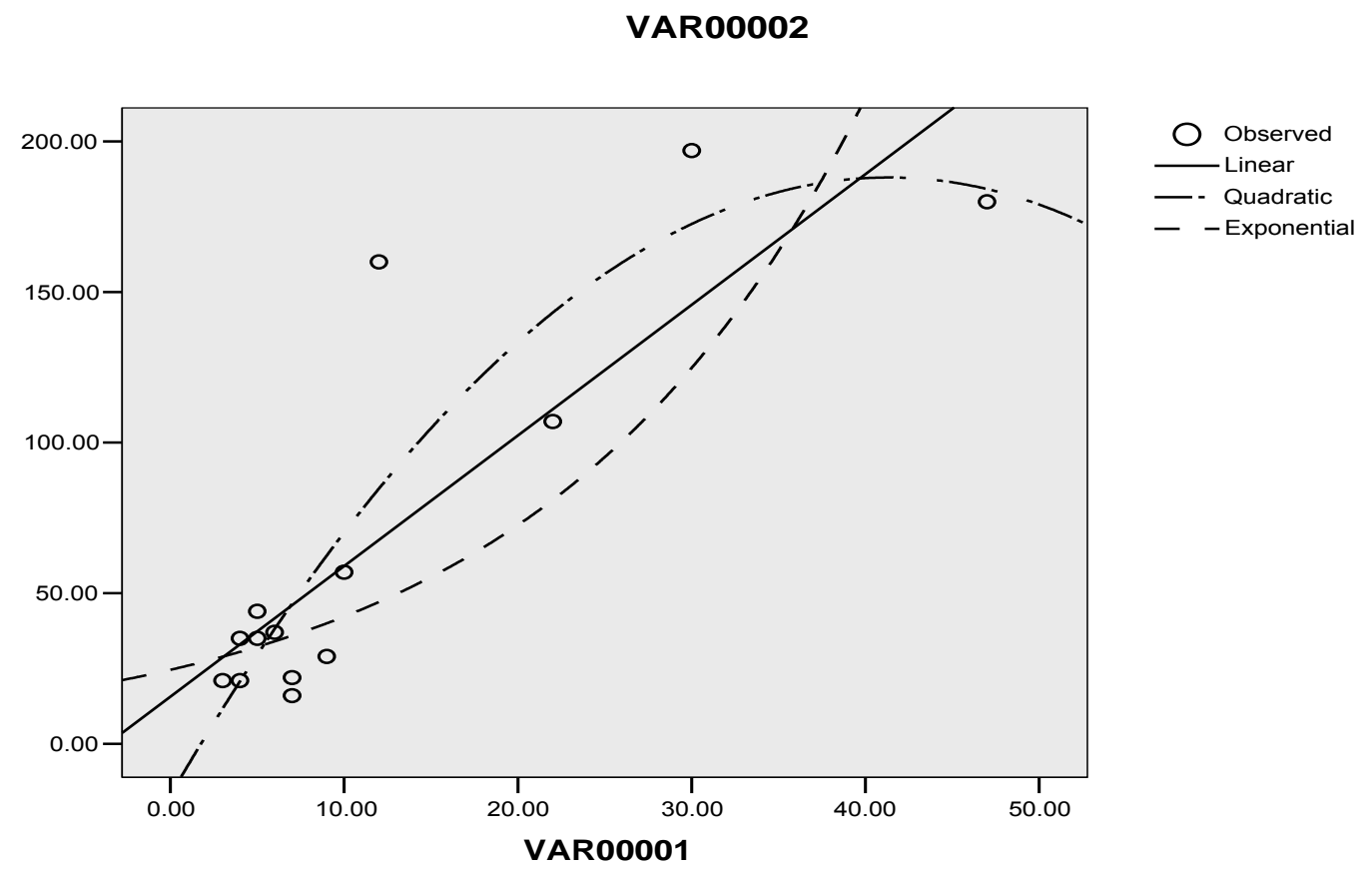

Graph1: Relationships among the Three Models

\section{PLANNIG IMPLICATIONS AND CONCLUSION}

The study has empirically established parking in the urban core of Uyo as a major road circulation problem. Many businesses in the central area are without their own parking places and the volume of their businesses seems to be adversely affected. However, field investigation by the authors has shown that vacant lands abound along the major streets of the city and they offer substantial amount of parking spaces.

Planning for parking facilities in the city should first start with identification and inventory of those vacant lands for car park development. These vacant lands can be built on the basis of either private or public ownership, and car owners can pay a fee to park their vehicles. Whatever strategy is adopted, the planning should be comprehensive enough to include the provision of on-street parking to augment demand where the road carriage way is wide enough to accommodate one-way parallel parking. Where the street width is inadequate to accommodate on-street parking, indiscriminate parking on the streets should be prohibited and such restriction must be well enforced. Also, parking in adjacent and unauthorized spaces, which are perpendicular to street corridors should be prohibited to ensure effective patronage of the 
designated parking areas as well as smooth circulation within the inner core of the city.

To implement this comprehensive parking program for the city, three issues must be addressed concurrently. First, designated parking areas need to be built in a way that maximizes the number and quality of spaces available. Second, directional signs to the parking and enhanced pedestrian walkways to connect the parking to businesses are essential to effective use of the parking facilities. Third, a unified parking management plan must be developed, implemented and enforced in order to coordinate use of the parking facilities. If well managed, the parking areas can be effective businesses in themselves.

\section{REFERENCES}

Bobadoye, S. A. and Fadamiro, J., 2006: Movement and Accessibility in the Urban Core: An investigation in Akure, Nigeria, in eds (J. A. Fadamiro, J. Olujimi, and A. Astrolabe) Urban Environmental sustainability; Interventions and Responses; Urban Design Research Team, School of Environmental Technology, Akure. Pp 31-43.

Dyckman, J., 1972. "Transportation in Cities" Scientific American, NY.

Etim, E. E., 2007. Streetscape Character and the Appearance of Nigerian Cities: A Case study of Uyo Urban in eds, O. B. Ekop;
E. Etim and J. D. Obot ; Physical Development of Urban Nigeria; Emerging Trends and Challenges, Universal Developmental Consortia, Ikot Ekpene; Pp 199-217.

Inter-City Design Partnership, 1998. Uyo Master Plan, for Akwa Ibom State

Kaiser I. Godschlk, D; and Chapin, F. S., 1995. Urban Land use Planning; University of Illinois Press, $4^{\text {th }}$ Edition, Urbana.

Johnson, J.H., 1972. Urban Geography; Pengamum Press, Oxford, London, $435 p$.

Obot, J. D. and Umoh, 2007. Problems and Prospects of Intra-City Transportation in Urban Nigeria; A case Study of Uyo Metropolis in eds , O. B. Ekop; E. Etim and J. D. Obot; physical Development of Urban Nigeria; Emerging Trends and Challenges, Universal Developmental Consortia, Ikot Ekpene; Pp 122-142.

Tanimowo, N. B. and Atolagbe, A. M., 2006. Land use and Intra-Urban Travels in Ogbomosho, Nigeria, in eds(J. A. Fadamiro et al,) Urban Environmental sustainability; Interventions and Responses; Urban Design Research Team, School of Environmental Technology, Akure. Pp 91-99. 